\title{
ASSOCIATION OF INFLAMMATORY STATUS OF PATIENTS WITH HISTOPATHOLOGICAL CHARACTERISTICS OF COLORECTAL TUMORS AND PERIOPERATIVE TRANSFUSION REQUIREMENTS
}

\author{
ANITA ŠTEFIĆ ${ }^{1}$, MARIJA SKOKO ${ }^{1}$, IRENA MIHIĆ LASAN ${ }^{1}$, IVA KIRAC ${ }^{2}$, \\ KARMEN BILIĆ ${ }^{1}$ and TIHA VUČEMILO ${ }^{1}$ \\ ${ }^{1}$ Department of Transfusion Medicine, University Hospital for Tumors, \\ University Hospital Center Sestre milosrdnice, Zagreb; \\ ${ }^{2}$ Department of Surgical Oncology, University Hospital for Tumors, \\ University Hospital Center Sestre milosrdnice
}

\begin{abstract}
Summary
Glasgow Prognostic Score (GPS) is such an inflammation-based factor, defined by the combination of the level of serum C-reactive protein (CRP) and albumin, which are indicators of systematic inflammatory response and nutritional status. A higher score is associated with a worse prognosis of different tumor sites. The score is based on the immunomodulatory and inflammatory status found in patients with elevated CRP. We hypothesized that there is a correlation between GPS and histopathological tumor characteristics and GPS and perioperative administration of erythrocyte concentrates in patients undergoing curative tumor resection. We retrospectively revied the data of fifty-one consecutive patient who underwent elective colorectal surgery. We extracted the values of preoperative C-reactive protein(CRP) and albumin and calculated the GPS. We correlated the histopathology of cancer and perioperative transfusion with the outcome. GPS 0 and 2 having a tumor localized in the colon, with GPS 1 in the rectum. T4 tumor stage had patients only in the group of GPS 2 which was statistically significant from the GPS 0 group. The GPS was not associated with the presence of metastases in the lymph nodes, lymphatic and perineural invasions, while a statistically significant difference was present comparing GPS with tumor deposits between GPS 0 and GPS 1 and GPS 0 and GPS 2. Transfusions were statistically significantly higher in GPS 2 group compared to GPS 0 and 1. A higher GPS score is associated with the changes of immune status of the tumor environment which can affect the recurrence of the disease and survival. GPS should be considered when recommending the frequency of follow up and therapy after curative tumor resection. We have shown that there is an increased risk for perioperative blood consumption, which may independently result in a worse prognosis of the underlying disease.
\end{abstract}

KEY WORDS: Glasgow prognostic score, colorectal cancer, tumor deposits, blood transfusion therapy

\section{POVEZANOST UPALNOG STATUSA, PATOHISTOLOŠKIH KARAKTERISTIKA I PERIOPERATIVNE POTREBE ZA TRANSFUZIJSKIM LIJEČENJEM U BOLESNIKA S KOLOREKTALNIM KARCINOMOM}

\section{Sažetak}

Prognostički upalni zbroj (Glasgow prognostic score, GPS) omogućava prognozu ishoda bolesti u osoba s rakom. Baziran je na serumskim biomarkerima C-reactivnom proteinu (CRP) i albuminu. Viši zbroj povezan je s lošijom prognozom bolesti. Mehanizam se temelji na imunomodulaciji i upalnom miljeu bolesnika s povišenim CRP-om. Resekcija debelog crijeva izvršena je u 51 bolesnika. CRP i albumini određeni su prije operacije. GPS je uspoređen s patohistološkim karakteristikama tumora i perioperacijskom transfuzijom koncentrata eritrocita. Utvrđeno je statistički značajna razlika u sijelu tumora analiziranih skupina.Značjano veći broj bolesnika s GPS 0 i 2 imao je tumor lokaliziran u kolonu, a s GPS 1 u rektu- 
mu. Tumorski stadij T4 imali su bolesnici samo u skupini GPS 2 što je statistički značajno različito od skupine GPS 0. GPS nije bio povezan s prisutnošću metastaza u limfne čvorove, limfatične i perineuralne invazije, dok je statistički značajna razlika bila u prisutnosti tumorskih depozita između GPS 0 i GPS 1, te GPS 0 i GPS 2. Statistički značajno češće krv je transfudirana bolesnicima GPS 2 skupine u odnosu na GPS 0 i 1. GPS je povezan s patohistološkim karakteristikama, povratom bolesti, preživljenjem i većim rizikom za primjenu krvi.

KLJUČNE RIJEČI: Glasgow prognostički zbroj, kolorektalni karcinom, tumorski depozit, transfuzija kroi

\section{INTRODUCTION}

The inflammatory response and malnutrition, perioperative treatment with blood products influence colorectal cancer prognosis. Inflammatory factors and malnutrition are components of Glasgow Prognostic Score (GPS): serum level of C-reactive protein (CRP) and serum albumin concentration. The higher scores associated with, the worse prognosis $(1,2)$. When the cancer cells stimulate the inflammatory response, the cytokine levels increase and the phenotype of the immune cells changes. Consequently, promotion of angiogenesis and inhibition of apoptosis and DNA damage and thus increases the malignant potential of cancer cells $(3,4,5)$. In this study, we hypothesized that there is a correlation of preoperative GPS value with histopathological characteristics of the colorectal tumor after curative surgical procedures. Likewise, we looked at the correlation of preoperative GPS with perioperative complications measured by higher blood loss (more than one dose of erythrocyte concentrate).

\section{PATIENTS AND METHODS}

At University Hospital for Tumors from 2014 to 2015, we retrospectively selected fifty-one patients with colorectal carcinomas surgically treated with curative intent. The age of patients ranged from 38 to 82 years, mean 65.1; 33 male and 18 female patients. We did not include patients with chronic inflammation in their history and neoadjuvant chemotherapy.

The blood samples were collected in tubes without anticoagulant immediately before surgery, and CRP and albumin analyzed. CRP and albumin were measured from serum obtained by centrifuging whole blood at $3500 \mathrm{rpm}$ for $10 \mathrm{~min}$. CRP and albumin tests were performed on automatic analyzer COBAS INTEGRA 400 plus manufactured by Roche using C-Reactive Protein (Latex) reagent (CRPLX) and Albumin Gen.2 reagent
(ALB2) from the same manufacturer. CRP measuring is based on the particle-enhanced turbidimetric assay. Human CRP agglutinates with latex particles coated with monoclonal anti-CRP antibodies. The precipitate is determined turbidimetrically at $552 \mathrm{~nm}$. Albumin concentration was measured by colorimetric assay with endpoint method. At a $\mathrm{pH}$ of 4.1 albumin displays a sufficiently cationic character to be able to bind with bromcresol green (BCG), an anionic dye, to form a blue-green complex. The color intensity of the blue-green color is directly proportional to the albumin concentration in the sample. It is determined by monitoring the increase in absorbance at $583 \mathrm{~nm}$. COBAS INTEGRA automatically calculates the analyte concentration of each sample (6). Blood consumption data were collected from the transfusion program, Delfin. Histopathological characteristics were obtained from the hospital system after surgery. Patients with CRP $>10 \mathrm{mg} / \mathrm{L}$ and albumin $<35 \mathrm{~g} / \mathrm{L}$ were classified in the GPS 2 group, only elevated CRP or lowered albumin level were classified into GPS 1 group and patients who did not have any of the characteristics in GPS 0 . Al statistical analysis was performed using MedCalc Version 18.11. The Chi-square test was used to determine statistically significant differences between histopathological parameters expressed in percentages between three groups of GPS 0,1 and 2 and the differences between the percentage of patients who received erythrocyte concentrations in these groups. $\mathrm{P}<0,05$ was considered significant.

\section{RESULTS}

The table shows the distribution of patients depending on the GPS and the histopathological characteristics of the tumor for each group. P1 represents the difference between GPS 0 and GPS 1 groups, p2 between GPS 1 and GPS 2 groups and p3 between GPS 0 and GPS 2 groups. Statistically significant differences were found in tumor posi- 
Lib Oncol. 2018;46(2-3):43-46

Table 1.

RELATIONSHIP BETWEEN GPS AND HISTOPATHOLOGICAL CHARACTERISTICS AND BLOOD

\begin{tabular}{|c|c|c|c|c|c|c|c|c|c|}
\hline & $\begin{array}{c}\text { GPS } 0 \\
(26)\end{array}$ & $\begin{array}{c}\text { GPS } 1 \\
(13)\end{array}$ & $\begin{array}{c}\text { GPS } 2 \\
(12)\end{array}$ & $\begin{array}{c}\text { GPS } 0 \\
(\%)\end{array}$ & $\begin{array}{c}\text { GPS } 1 \\
(\%)\end{array}$ & $\begin{array}{c}\text { GPS } 2 \\
(\%)\end{array}$ & $\mathrm{p} 1$ & p2 & p3 \\
\hline All & & & & 51 & 25 & 24 & & & \\
\hline Colon & 19 & 5 & 10 & 73 & 38 & 83 & 0,02 & 0,02 & 0,46 \\
\hline Rectum & 7 & 8 & 2 & 27 & 62 & 17 & 0,02 & 0,01 & 0,45 \\
\hline \multicolumn{10}{|l|}{ Depth of tumor } \\
\hline $\mathrm{T} 1$ & 8 & 2 & 0 & 30 & 15 & 0 & 0,21 & 0,22 & 0,03 \\
\hline T2 & 3 & 5 & 2 & 12 & 38 & 16 & 0,07 & 0,19 & 0,88 \\
\hline T3 & 15 & 6 & 9 & 58 & 47 & 75 & 0,71 & 0,28 & 0,38 \\
\hline T4 & & & 1 & & & 9 & 0,05 & 0,17 & 0,05 \\
\hline \multicolumn{10}{|c|}{ Nodal metastasis } \\
\hline No & 11 & 7 & 9 & 42 & 54 & 75 & 0,76 & 0,28 & 0,12 \\
\hline Yes & 15 & 6 & 3 & 58 & 46 & 25 & 0,73 & 0,28 & 0,12 \\
\hline \multicolumn{10}{|c|}{ Lyphatic invasion } \\
\hline No & 21 & 11 & 9 & 81 & 85 & 75 & 0,63 & 0,33 & 0,5 \\
\hline Yes & 5 & 2 & 3 & 19 & 15 & 25 & 0,63 & 0,33 & 0,5 \\
\hline \multicolumn{10}{|c|}{ Perineural invasion } \\
\hline No & 26 & 13 & 12 & 100 & 100 & 100 & & & \\
\hline Yes & 0 & 0 & 0 & 0 & 0 & 0 & & & \\
\hline \multicolumn{10}{|c|}{ Tumor deposits } \\
\hline Yes & 8 & 11 & 12 & 31 & 85 & 100 & 0,001 & 0,24 & 0,001 \\
\hline No & 18 & 2 & 0 & 69 & 15 & 0 & 0,001 & 0,22 & 0,0001 \\
\hline $\begin{array}{l}\text { Perioperative } \\
\text { transfusion }\end{array}$ & 10 & 3 & 9 & 38 & 25 & 75 & 0,44 & 0,02 & 0,05 \\
\hline
\end{tabular}

GPS, Glasgow prognostic score; lelels of statistical significance obtained by comparison of two groups p1 (GPS0 vs. GPS1), p2 (GPS1 vs. GPS2), p3 (GPS0 vs. GPS2).

tion between analyzed groups, with a higher number of patients with GPS 0 and 2 having a tumor localized in the colon, GPS 1 in the rectum. Stage T4 was found in the group with GPS 2 which was significantly different from the GPS 0 group. For metastases in the lymph nodes, the lymphatic and perineural invasion there was no difference between the three groups, while a statistically significant difference was observed in the presence of tumor deposits between GPS 0 and GPS 1 and GPS 0 and GPS 2. Statistically significant more blood was transfused to the patients of the GPS2 group compared to GPS 0 and 1.Transfusions were higher in GPS2 group compared to GPS 0 and 1.

\section{DISCUSSION}

Glasgow prognostic score (GPS), is a combination of serum CRP and albumin levels, an inflammatory score which assesses the malignant potential of different cancers. GPS is used as a prognostic factor for various gastrointestinal tu- mors $(7,8)$ but was first descibed for lung cancer in 2003.(9). Malignant potential is determined primarily by histopathological characteristics but should include other modifiers such as GPS.

We demonstrated the correlation between preoperative inflammatory and nutritional status in patients with histopathological tumor characteristics and their influence on postoperative complications such as blood loss and transfusion needs. Given the statistically significant difference between the groups in the presence of tumor deposits, we suggest that GPS might be a significant indicator of possible distant metastases and poor prognosis, regardless of other characteristics such as lymphatic, perineural and lymphovascular invasion. The existence of tumor deposits correlates with a worse prognosis for lower disease stages (10). Higher GPS correlates with the incidence of distant metastases for T1 and T2 cancers (11). Increased level of preoperative CRP correlates with T lymphocyte immunomodulation and low infiltration of T lymphocytes into tumor., which may 
trigger tumor progression in patients undergoing curative colorectal resection $(12,13)$. The mechanism of immunomodulation probably presented here is similar to ones described for immunomodulation induced by transfusions (14). We have shown that transfusion is more common in patients with hypoalbuminemia and elevated CRP compared to patients who had a single factor or none. Some studies show that preoperative anemia correlates with right-sided tumors, greater depth of tumor invasion, use of neoadjuvant chemotherapy, poor prognostic nutritional index and higher modified Glasgow Prognostic Score (mGPS). The microcytic anemia, in particular, is strongly associated with the greater depth of tumor invasion $(\mathrm{P}=0.0072)$ and higher mGPS $(\mathrm{P}=$ 0.0058 ) than other causes of anemia. Perioperative blood transfusion for CRC patients with anemia correlates with adverse outcomes (15). Hypoalbuminemia is also a risk factor for perioperative transfusion and survival of patients who had a liver resection (16).

\section{CONCLUSION}

Combination of changes in inflammatory status and perioperative blood application may influence the poor prognosis of the disease and referral to other types of treatment after the curative operation, regardless of the histopathological status of the tumor itself. However, extensive prospective research is needed on a more significant number of patients and five years follow up to determine the actual impact on the survival and recurrence of the disease.

\section{REFERENCES}

1. Roxburgh CS, Mc Millan DC. Role of systemic inflammatory response in predicting survival in patients with primary operable cancer. Future Oncol. 2010;6 (1):149-63.

2. Radahiro N, Rumi M, Hideki I, Takefumi O, Takahiro E. Glasgow Prognostic Score (GPS) can be a useful indicator to determine prognosis of patients with colorectal carcinoma. Int Surg. 2014;99:512-7.

3. Balkwill F, Mantovani A. Inflammation and cancer: Back to Virchow? Lancet. 2001;357:539-45.

4. Jaiswal M, LaRusso NF, Burgart LJ, Goress GJ. Inflammatory cytokines induce DNA damage and inhibit DNA repair in cholangiocarcinoma cells by a nitric oxide-dependent mehanisams. Cancer Res. 2000;60: 184-90.
5. Jackson JR, Seed MP, Kircher CH, Willoughby DA, Winkler JD. The codependence of angiogenesis and chronic inflammation. FASEB J. 1997;11:457-65.

6. www.roche.com

7. McMillan DC, Crozier JE, Canna K, Angerson WJ, McArdle CS. Evaluation of an inflammation-based prognostic score (GPS) in patients undergoing resection for colon and rectal cancer. Int J Colorectal Dis. 2007;22(8):881-6.

8. Crumley AB, Stuart RC, McKernan M, McMillan DC. Is hypoalbuminemia an independent prognostic factor in patients with gastric cancer? World J Surg. 2010;34(10):2393-8.

9. Forrest LM, McMillan DC, McArdle CS, Angerson WJ, Dunlop DJ. Evaluation of cumulative prognostic scores based on the systemic inflammatory response in patients with inoperable non-small cell lung cancer. Br J Cancer 2003;89:1028-30.

10. Nagayoshi K, Ueki T, Nishioka Y, et al. Tumor deposit is a poor prognostic indicator for patients who have stage II and III colorectal cancer with fewer than 4 lymph node metastases but not for those with 4 or more. Diseases of the Colon and Rectum. 2014;57(4): $467-74$.

11. Ishizuka M, Nagata H, Takagi K, Kubota K. Systemic inflammatory response associated with distant metastasis of T1 or T2 colorectal cancer. Dig Dis Sci. 2010; 55(11):3181-7.

12. Noze T, Matsumata T, Sugimachi K. Preoperative elevation of serum $\mathrm{C}$-reacitve protein i related to impaired immunity in patients with colorectal cancer. Am J Clin Oncol. 2000;23:263-6.

13. Canna K, McArdle PA, McMillan DC, McNicol AM, Smith GW, McKee RF. et al. The relationship between tumor T-lymphocyte infiltration, the systemic inflammatory response and survival in patients undergoing curative resection for colorectal cancer. Br J Cancer. 2005;92:651-4.

14. Amato A, Pescatori M. Perioperative blood transfusions for the recurrence of colorectal cancer. Cochrane Database Syst Rev. 2006;CD005033.

15. Tokunaga R, Nakagawa S, Miyamoto $Y$, Ohuchi M, Izumi D, Kosumi K, Taki K, Higashi T, Miyata T, Yoshida N, Baba $\mathrm{H}$. The impact of preoperative anaemia and anaemic subtype on patient outcome in colorectal cancer.Colorectal Dis. 2019 Jan;21(1):100-109. doi: 10.1111/codi.14425. Epub 2018 Oct 11.

16. Hanazaki K, Kajakawa S, Shimozawa N, Matsushita A, Machida T, Shimada K, et al. Perioperative blood transfusion and survival following curative hepatic resection for hepatocellular carcinoma. Hepato-gastroenterology. 2005;52:524-9.

Corresponding author: Marija Skoko, Department of Transfusion Medicine, Sestre milosrdnice University Hospital Center, Ilica 197, 10000 Zagreb, Croatia. e-mail: skomar.11@gmail.com 